\title{
Ballast Water Research at the WERC
}

Invasive aquatic species are considered to be one of the greatest threats to marine biodiversity, coastal economies, and even human health. Ballast water is a primary vector for these bioinvasions. One method of reducing risk of ballast water introductions is mid-ocean exchange of marine ballast water. However, it is widely recognized that this practice has many limitations, including serious ship safety concerns and variable biological effectiveness.

International agencies and federal, state and local governments are attempting to tackle the problem by recommending or mandating the installation of ballast water treatment systems. The WFRC is working with others to develop new technologies to detect, prevent, and control aquatic invasive species impacts in Puget Sound and the Pacific Northwest.

\section{WFRC Studies Ballast Water}

Although there are several vectors for invasive marine species such as aquaculture, recreational boats, and public aquaria, the most important transportation vector is ballast water carried in commercial ships. Today there are more than 45,000 commercial cargo-carrying vessels that use ballast water to maintain stability when cargo loads vary. Puget Sound is home to major seaports of national and international importance. Elsewhere in the Pacific Northwest, such as the Columbia River, significant ports are located far inland (e.g., Portland, Oregon) or in other estuarine settings. The region's strategic importance in Asia-Pacific trade makes it exceptionally vulnerable to ballast water introductions.

One ship may contain more than 12 million gallons of ballast water providing a very efficient vector for aquatic microbes, plants, and animals. In fact, it is estimated that 7,000 different species are transported around the world daily in ballast water. Therefore, there is a critical need to develop tools to detect and eradicate invasive species in ballast water prior to their release and establishment in coastal ecosystems. At WFRC, scientists are working to develop DNA markers to detect and monitor invasive species in ballast water. These molecular tools offer great promise as a rapid assessment technique to evaluate the effectiveness of oceanic exchange which occurs off the West Coast for domestic shipments and across the NE Pacific for international carriers. Using state-of-the-art

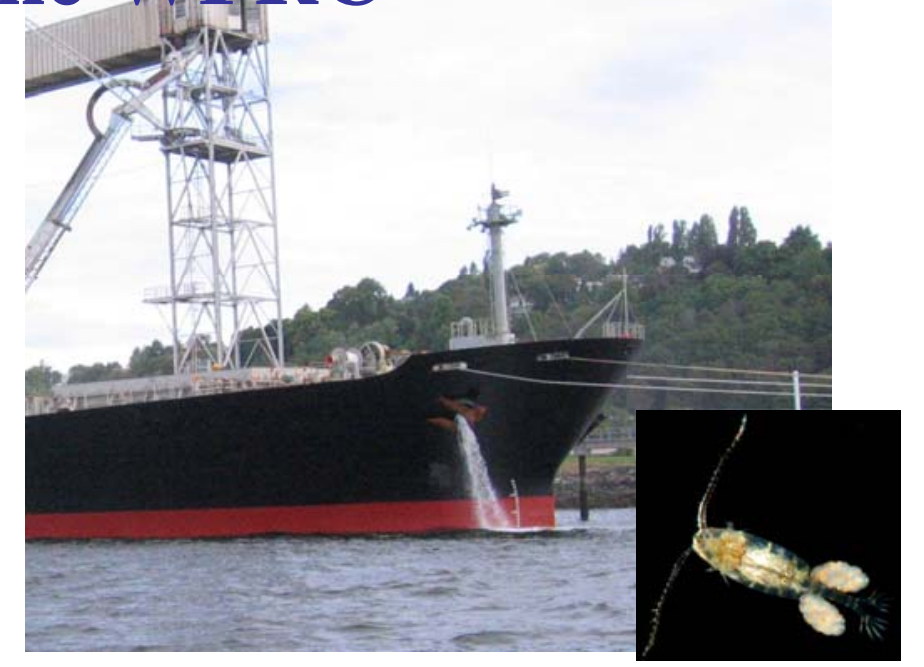

Water is pumped into vast tanks to stabilize a vessel, and later the ballast water is discharged. In this way, animals and plants, like the copepod shown above, can be transported thousands of kilometers from their native habitats and deposited in a new environment.

technology, we are developing diagnostic systems that will allow as many as 20,000 species to be detected at one time. This technology will give state and federal regulators the tools they need to monitor how clean ballast water is before it is dumped in coastal ports. Additional analyses of ballast water samples collected in Puget Sound are underway at the WFRC for quantification of bacterial and phytoplankton pre- and post eradication applications.

\section{Prevention and Control of Marine Ballast Water Organisms.}

For the past 4 years, the WFRC and University of Washington partners, have performed ballast water treatment experiments at the USGS's, Marrowstone Marine Field Station in northern Puget Sound. Intermediate scale, 75-gallon (280L) circular fish tanks, were utilized for the

\section{Challenges for Treatment Technologies}

- Kills the toughest organisms.

- Environmentally friendly
- Safe for crew. sensitive bioassay organism that environmental agency chooses.

- Noncorrosive to ballast tanks.

- Relatively inexpensive.

- Verification, certification, enforcement. 
ballast experiments. Experimental treatments and controls were replicated by using four tanks per replicate. The tank volume was sufficient to allow re-sampling four or more times during an experiment. Thus far, we have examined the effects of exposure of ultraviolet light, SeaKleen ${ }^{\circledR}$, ozone, and electrolytically generated sodium hypochlorite on the survival of planktonic organisms characteristic of Puget Sound. The biological parameters measured included bacteria numbers, heterotrophic bacteria (deriving nourishment from organic substances), chlorophyll $a$, phytoplankton, and zooplankton. For the experiments oxidizing biocides, like ozone and disinfection byproducts were measured.

\section{Highlights of Experimental Results Include:}

\section{Summary of UV Results}

Bacteria and phytoplankton more sensitive to UV than zooplankton.

- $50-75 \mathrm{~mJ} \mathrm{~cm}^{-2}$ yields a 4 or more log reduction of viable bacteria.

- $300 \mathrm{~mJ} \mathrm{~cm}^{-2}$ necessary for rapid death of zooplankton.

\section{Filtration + Chlorination}

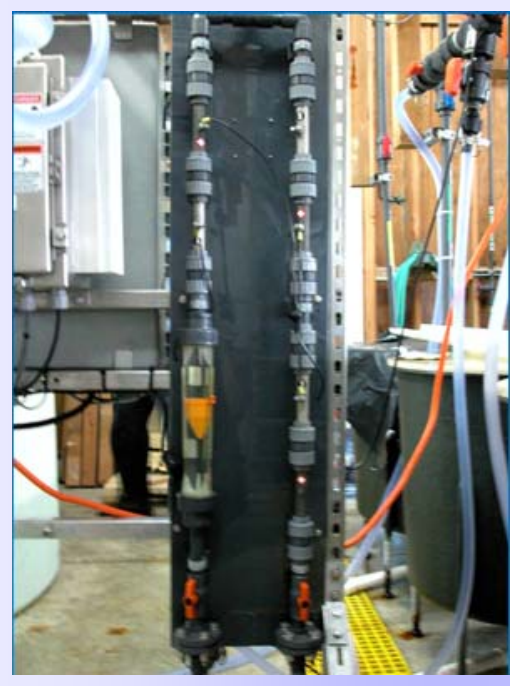

Prototypic Treatment Technology at USGS Marrowstone Marine Field Station. Three electrolytic cells are used to generate hypochlorite from seawater (NaCl). Each cell consists of a cathode and an anode.

Filtration+Chlorine: Zooplankton

\section{Live Zooplankton Per Liter}

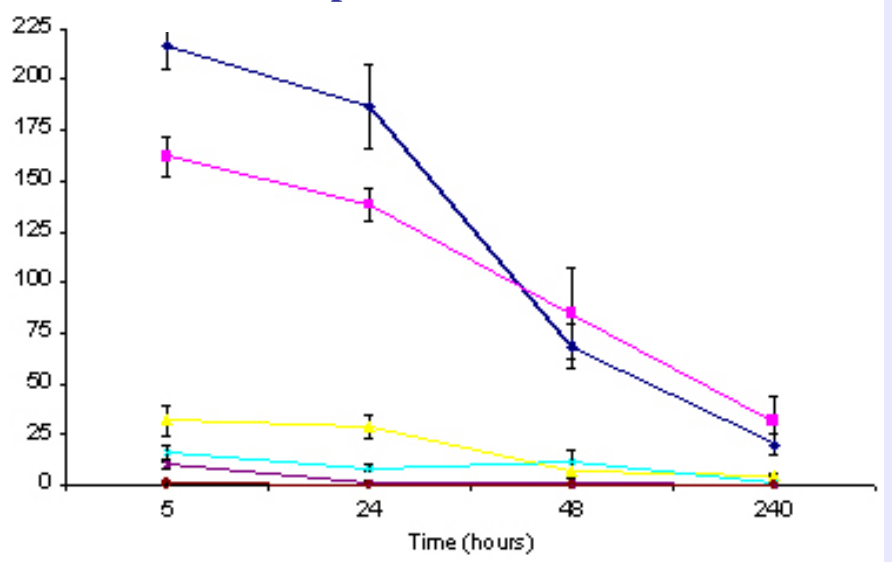

Lethality of UV may not be instantaneous for larger taxa. Sub-lethal doses may induce stress effects (e.g. activity, spawning).

\section{Research Results from Experiments with Filtration and Chlorine are Most Promising.}

Within 5 hours post treatment:

- filtration reduced zooplankton numbers by 83-89 percent.

- $\quad 1.0-1.5$ ppm chlorine decreased zooplankton abundance 87-93 percent.

- 0.5 ppm chlorine with filtration killed most of the zooplankton.

Immediately after filtration + chlorination, bacterial levels dropped by more than 50 percent. However, over time bacteria rebounded and bacterial counts in treated groups were two times higher than in untreated groups at the end of the study. Filtration without chlorination was not effective at reducing bacterial counts. Filtration + chlorine was very effective at reducing phytoplankton numbers; most of the removal resulted from the chlorine. (See sidebar)

\section{Detection of Invasive Species}

WFRC scientists are developing species specific DNAbased diagnostic systems to detect non-native species in ballast water and to study invasion pathways in Puget Sound. A community approach using microarrays and fluorescing molecular beacons was chosen because rapid, high fidelity techniques are necessary to analyze and identify all life stages of marine organisms that may be carried in ballast water. A critical aspect of this tool development is converting the target DNA from a double stranded molecule to single stranded molecule so it may bind to diagnostic beacons. To date, 24 species-specific diagnostic markers for native and non-native bivalves and crustaceans have been developed. Protocols to efficiently extract DNA from planktonic life history stages are being developed. The extraction protocol will provide the sensitivity needed to detect as few as 250 larvae per water sample from ballast tanks or nature.

By the end of 2006, the WFRC will have a complete collection of all native and introduced clams in Puget Sound. Diagnostic systems will be completed by winter and we will begin to coordinate with State managers to screen ballast water in ships entering Puget Sound. Because the ballast water invasive pathways are international in scope, the WFRC is also acquiring biological samples from a number of Pacific ports.

The development of DNA markers from foreign ports will eventually allow agencies to determine the identity and origins of organisms present in ballast water. 
Conceptual Model of Molecular Diagnostic Systems

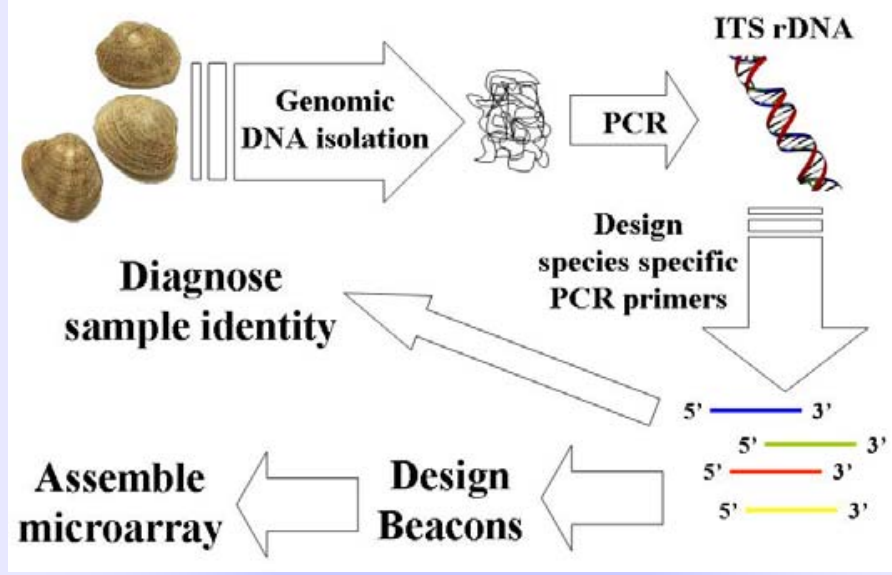

How Molecular Beacons Work

before hybridization

after hybridization

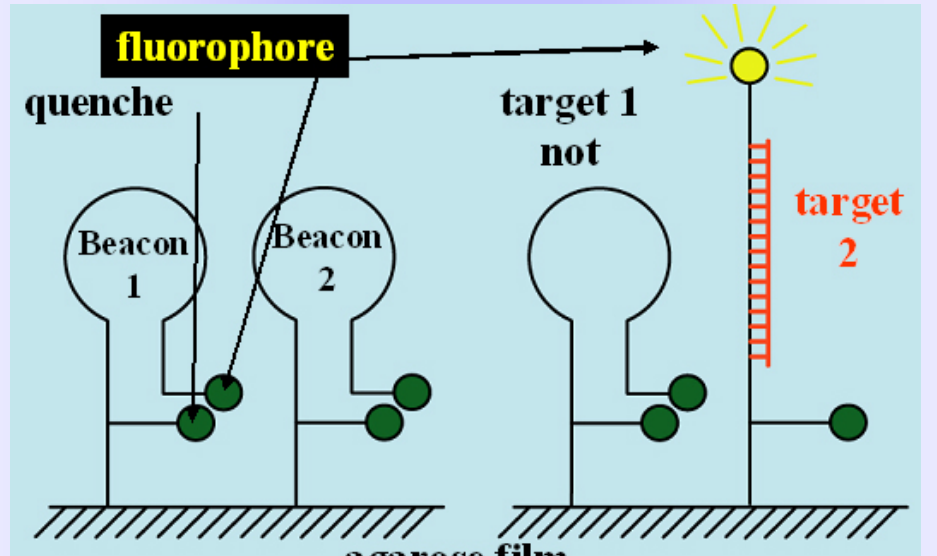

agarose film

Testing an Environmental Sample

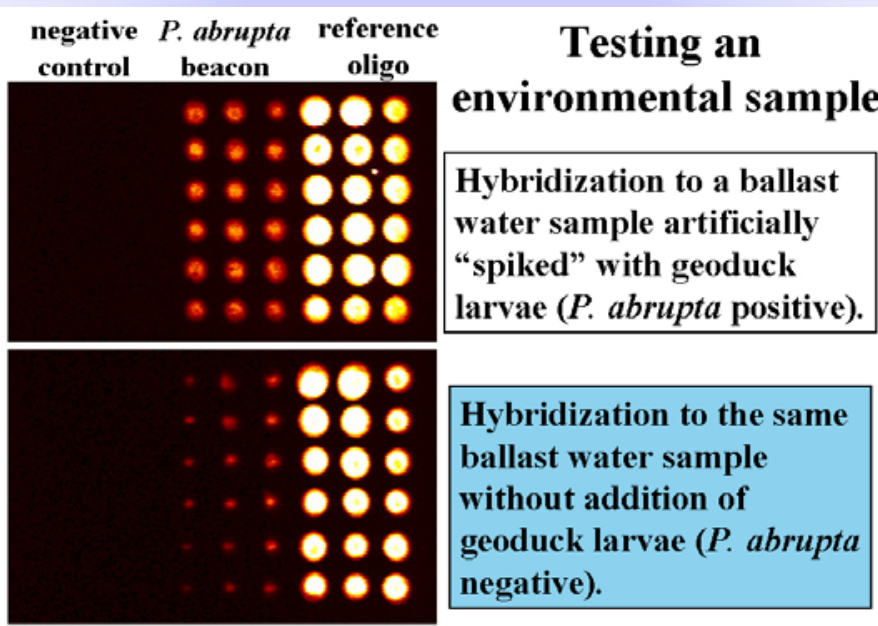

\section{Risk Assessment}

DNA-based detection tools are being used to analyze the distribution, establishment and ecology of invasive bivalves and crustaceans around Puget Sound. Geospatial data from these analyses will be used to assess risk of invasion to native and commercial species. Invasive tunicates, green crabs, and Spartina are of special interest in Puget Sound and to the Washington State Aquatic Nuisance Species Committee of which the WFRC is a member. The WFRC is providing geospatial database services and GIS support to the Committee.

\section{Regional Testing and Evaluation Facility}

In March 2006, the WFRC received a start-up grant from the NOAA National Sea Grant and U.S. Fish and Wildlife Ballast Water programs to develop a full proposal for a research, development, test and evaluation (RDTE) facility in Puget Sound. The full proposal will describe facility requirements necessary to conduct cooperative research on (1) ballast water treatment technologies; and the (2) biology and ecology of invasive species for the Pacific Northwest region, Oregon to Alaska. FY 2007 activities will include preparation of preliminary concept designs for: modifications and expansion of the Marrowstone Marine Field Station facility; modifications and development of the existing University Washington freshwater facility; and building a ballast water treatment test bed on a barge. Considerations will be given for either constructing a new barge or modifying an existing MARAD-owned barge. The possibilities and costs for using a barge will be compared to a land-based test bed alternative. The University of Washington, and the Glosten Associates Inc. are WFRC cooperators on this new project.

\section{Research

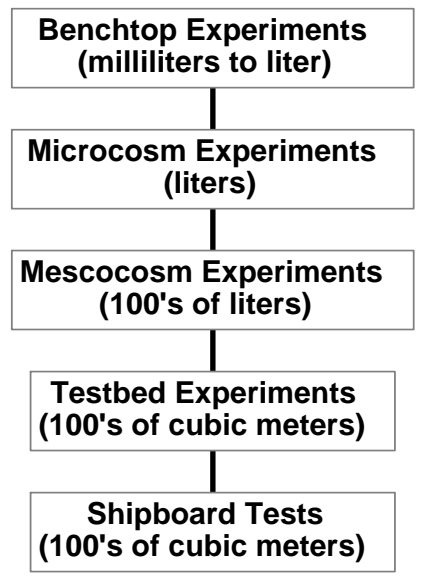

Suggested Model for Performing Ballast Water Treatment

Ideally, experiments of potential treatment technologies should begin with experiments being performed at scales identified at the top of the figure. The model demonstrates the need to have experimental capability at various scales including at an intermediate scale (which will be proposed for USGS at the Marrowstone Island facility. The Marrowstone facility will be an important site for vendors to have prototype treatment systems tested.

\section{Science Cooperators and Partners}

The WFRC's science cooperators and partners in the Pacific Northwest include the University of Washington (School of Ocean and Fisheries, Biology Department, and Washington Sea Grant Program, Urban Waters Marine Research Center - Tacoma), University of San Francisco, University of Purdue, Washington Department of Fish and Wildlife, the 


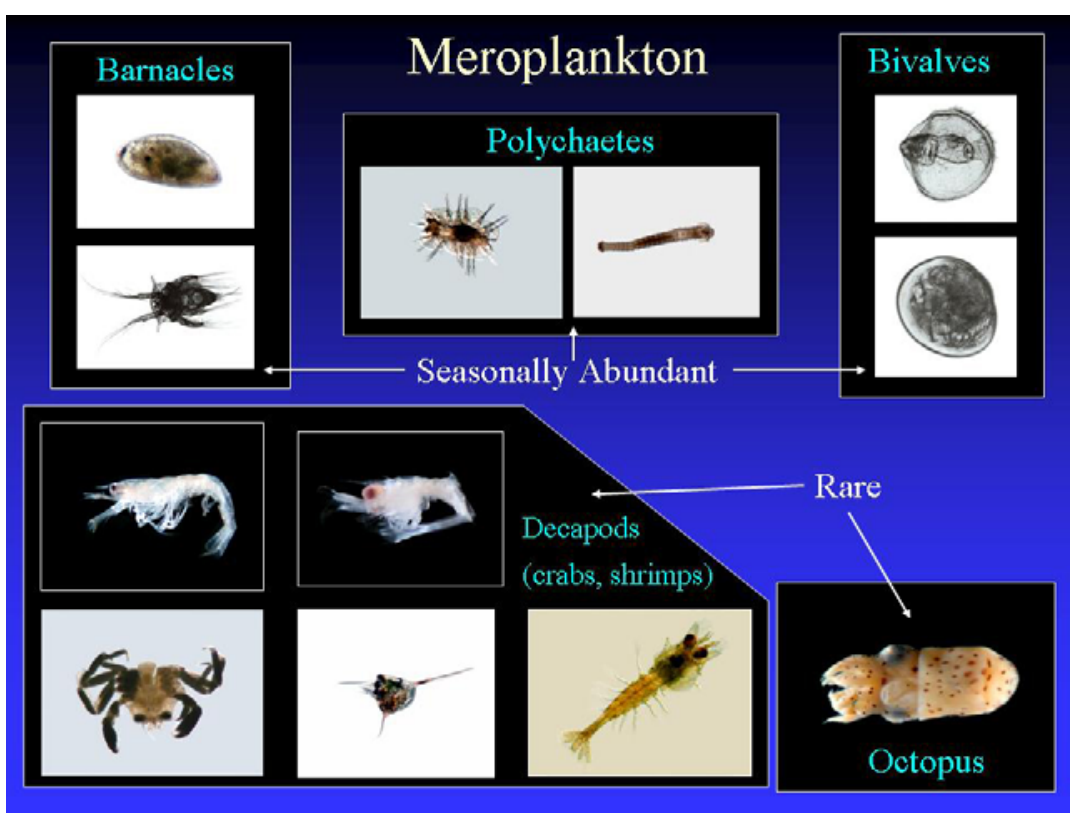
sea floor.

U.S. Navy, U.S. Fish and Wildlife Service, Environmental Protection Agency, State of Alaska, National Oceanic and Atmospheric Administation (Sea Grant, NOAA Fisheries, and National Ocean Service), Department of Homeland Security- U.S. Coast Guard, Maritime Administration, Northeast Midwest Institute, and Smithsonian Environmental Research Center. Other cooperators and partners include the port authorities for Seattle and Tacoma, Puget Sound Action Team, Battelle Marine Sciences Laboratory, BP Exploration, Prince William Sound Regional Citizens Advisory Committee.

\section{Selected Science Products}

Herwig, R.P., J.R. Cordell, J.C. Perrins, P.A. Dinnel, R.W. Gensemer, W.A. Stubblefield, G.M. Ruiz, J.A. Kopp, M.L. House, W. J. Cooper. 2006. Ozone treatment of ballast water on the oil tanker $S / T$ Tonsina: chemistry, technology to treat ballast water on ships. Appl. Environment. Microbiol.

Hershberger, P.K., S.A. Hart, J. Gregg, N.E. Elder, and J.R. Winton. In Press. Dynamics of viral hemorrhagic septicemia, viral erythrocytic necrosis, and Ichthyophoniasis in juvenile Pacific herring. Diseases of Aquatic Organisms.

Herwig, R.P., J.R. Cordell, S.M. Bollens, J.L. Grocock, N.C. Ferm, G. Rollwagen-Bollens, A. Slaughter, and J. Fulmer. In press. Effects of UV radiation on marine plankton communities: implications for ballast water treatment. Mar. Eco. Prog. Ser.

Cangelosi, A., and N. Mays. 2004. Summary and Findings of the Ballast Discharge Monitoring Device Workshop, Marrowstone Marine Field Station, Olympic Peninsula, WA, USA, August 12-16, 2002. NortheastMidwest Institute, Washington D.C.

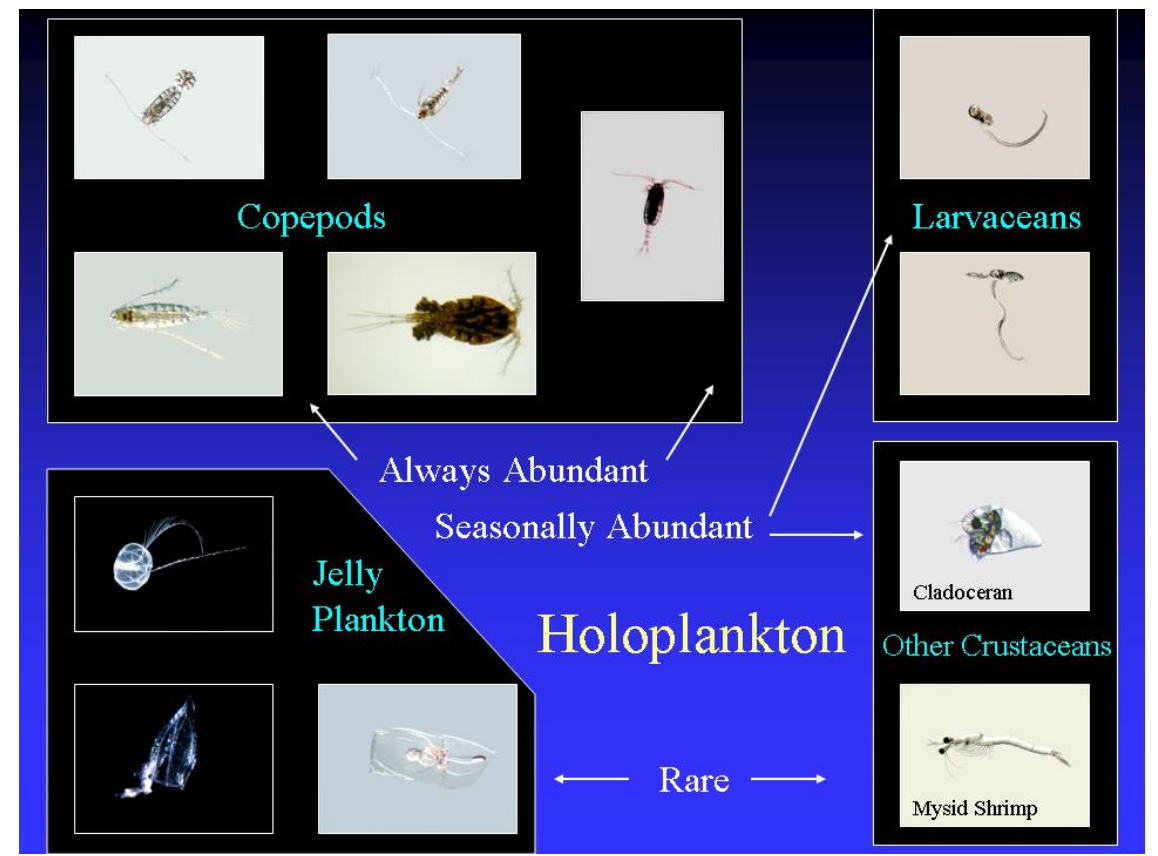

Species found in Puget Sound ballast water. Meroplankton are species that have planktonic early life history stages (eggs and larvae) but adults dwell on the

Photos provided by Jeff Cordell.

biology, and toxicity. Mar. Ecol. Prog. Ser.

Paulson, B.A., E.R. Blatchley III, S. Chaiyapechara, and R.P. Herwig. In Press. Effect of ultraviolet light on marine heterotrophic bacteria: evaluation of a
Species found in Puget Sound ballast water. Holoplankton are planktonic species that are pelagically distributed through the whole of their life cycles.

Photos provided by Jeff Cordell.

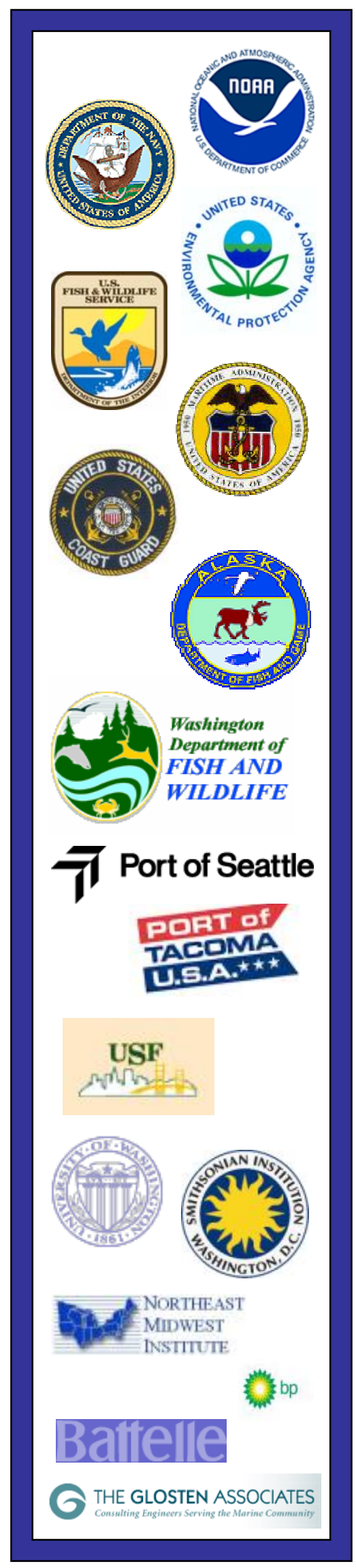

For Additional Information, Please Contact:

Lyman Thorsteinson, Center Director U.S. Geological Survey

Western Fisheries Research Center 6505 NE $65^{\text {th }}$ Street Seattle, WA 98115
Phone: (206-526-6282 FAX (206) 526-6654 http://wfrc.usgs.gov 